\title{
In Situ Stress Distribution and Its Control on the Coalbed Methane Reservoir Permeability in Liulin Area, Eastern Ordos Basin, China
}

\author{
Peng Feng $\mathbb{D}$, ${ }^{1,2}$ Song Li $\mathbb{D}^{1,2}$ Dazhen Tang $\mathbb{D},{ }^{1,2}$ Liangjun $W u\left(\mathbb{D},{ }^{3}\right.$ Yan Zhang $\mathbb{D},{ }^{1,2}$ \\ and Guanghao Zhong $\mathbb{( I ) ~}^{1,2}$ \\ ${ }^{1}$ School of Energy Resources, China University of Geosciences (Beijing), Beijing 100083, China \\ ${ }^{2}$ Coal Reservoir Laboratory of National Engineering Research Center of CBM Development \& Utilization, China University of \\ Geosciences (Beijing), Beijing 100083, China \\ ${ }^{3}$ Changqing Oilfield Company Oil Production Plant No. 8, China
}

Correspondence should be addressed to Song Li; lisong@cugb.edu.cn

Received 9 March 2021; Accepted 7 May 2021; Published 25 May 2021

Academic Editor: Andrew Manning

Copyright (c) 2021 Peng Feng et al. This is an open access article distributed under the Creative Commons Attribution License, which permits unrestricted use, distribution, and reproduction in any medium, provided the original work is properly cited.

\begin{abstract}
Permeability is one of the important factors that affect the production efficiency of coalbed methane, and it is mainly controlled by in situ stress. Therefore, it is very essential to study the in situ stress and permeability for the extraction of coalbed methane. Based on the injection/falloff well test and in situ stress measurement of 35 coalbed methane wells in the Liulin area in the east of the Ordos basin, the correlations between initial reservoir pressure, in situ stress, lateral stress coefficient, permeability, and burial depth were determined. Finally, the distribution characteristics of in situ stress and its influence on permeability were analyzed systematically. The results show that with the increase of burial depth, the initial reservoir pressure and in situ stress both increase, while the lateral stress coefficient decreases. The permeability variation is related to the type of stress field in different burial depths, and its essence is the deformation and destruction of coal pore structures caused by stress. The distribution characteristics of in situ stress at different depths and its effect on permeability are as follows: at depths $<800 \mathrm{~m}$, the horizontal principal stress is dominant $\left(\sigma_{\mathrm{H}} \geq \sigma_{\mathrm{v}}>\sigma_{\mathrm{h}}\right)$ and the permeability is a simple decreasing process with the increase of the depth; at depths $>800 \mathrm{~m}$, the vertical stress is dominant $\left(\sigma_{\mathrm{v}} \geq \sigma_{\mathrm{H}}>\sigma_{\mathrm{h}}\right)$. The permeability of most coal is very small due to the large in situ stresses in this depth zone. However, because of the stress release at the syncline axis, coal with high permeability is still possible at this depth zone. Due to the existence of high permeability data points at burial depth $(>800 \mathrm{~m})$ and the fitting relationship between permeability and vertical stress, the maximum and minimum horizontal principal stress is poor. However, the coal permeability and lateral stress coefficient show a good negative exponential relationship. This indicates that the lateral stress coefficient can be used to predict permeability better.
\end{abstract}

\section{Introduction}

In situ stress is a type of internal stress in the Earth's crust, which is mainly controlled by gravity and tectonic activity [1-5]. Permeability is one of the important factors affecting the efficiency of coalbed methane (CBM) production. Because the porosity and permeability of coal seams are very low, the commercial production capacity of coal seams can only be improved through large-scale fracturing, and in situ stress is the key factor affecting the effect of fracturing [6-8]. In situ stress can also help predict permeability and fluid flow in coalbed methane reservoirs [9-12]. The vertical stress is relatively simple and is mainly affected by the overlying rock mass. The horizontal principal stress is 


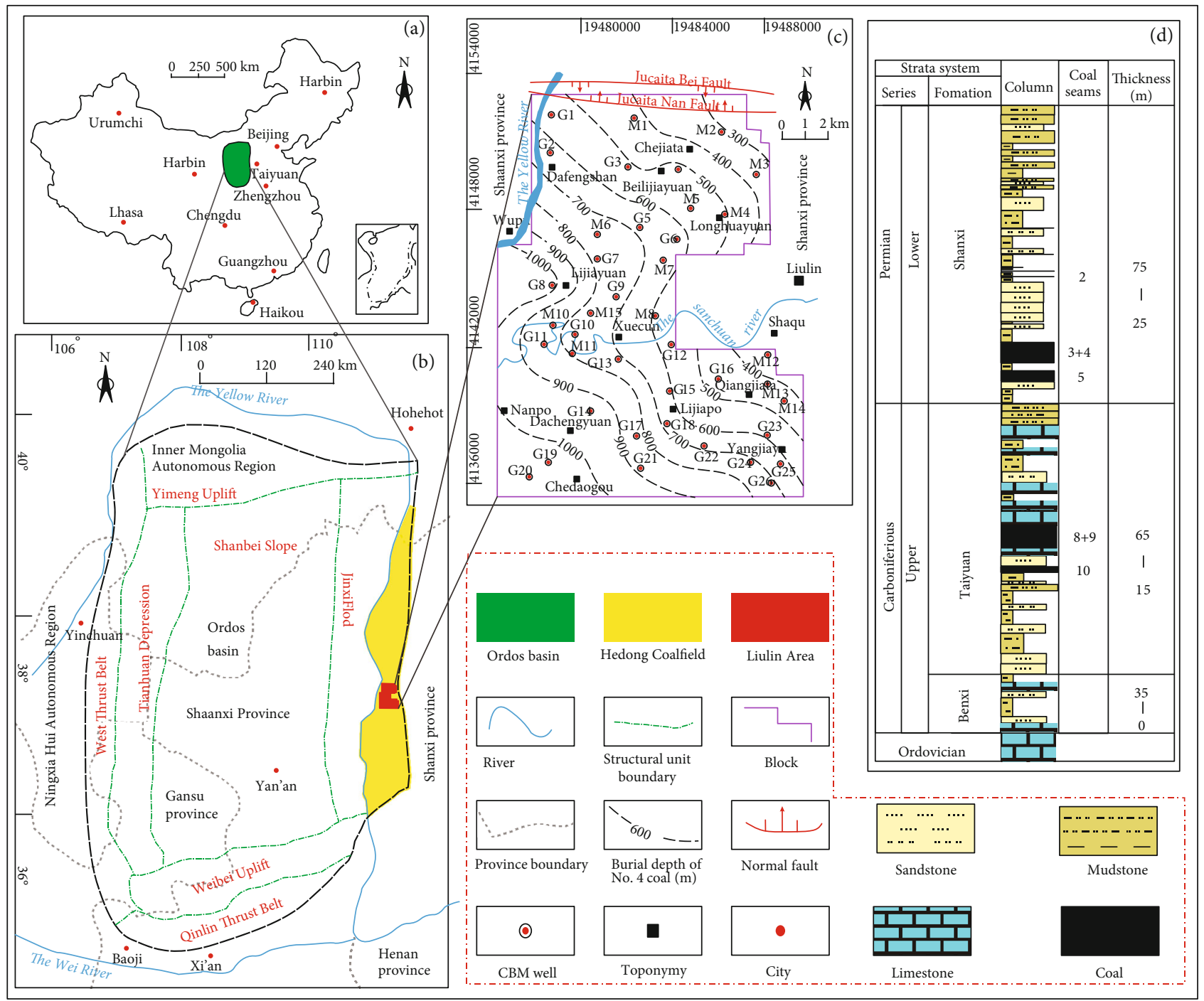

Figure 1: Location of the Liulin area: (a) locations of the Ordos basin in the China map; (b) general location of the eastern margin of the Ordos basin in the tectonic division map; (c) specific locations of the CBM blocks and wells in the eastern margin of the Liulin area; (d) composite stratigraphic column showing coal-bearing formations in the Liulin area.

mainly influenced by tectonic activity and rock geological activity, and it is much more complex because it is constantly changing over time [13]. Clearly, it is an indispensable link for the extraction of coalbed methane to study the in situ stress and permeability of coal seams [14-19].

The Ordos basin is located in the middle of the North China Plate and has become the second largest coalbed methane development base after the Qinshui Basin since the 1980s [20-23]. Liulin area is located in the east of the Ordos basin. Due to the advantages of many layers of coal, large thickness, high gas content, simple geological structure, and moderate burial depth, this area has attracted extensive attention of coalbed methane geologists. In the 1990s, Liulin area was even called "China's San Juan" by geologists. Enron, Phillips, ARCO, BP, Texaco, Lowell, PetroChina, and Sinopec have successively conducted coalbed methane exploration in this area. Liulin area has become a new highlight of typical medium-size coalbed methane exploration and development in China [24-26].

Up to now, little research has been carried out on the geology of the coalbed methane field in the Liulin area. For example, some of the specific studies include the following: the porous characteristics of coal developed in different coal facies have been studied [27]; the causes of abnormally high pressure in the Carboniferous No. 8 coal reservoir were considered to be closely related to local hydrodynamic traps [24]; the characteristics of water production during coalbed methane extraction were studied by analyzing stable isotopes in groundwater [28]; the coalbed methane preservation mechanism was researched by analyzing coalbed methane geology, hydrogeology, and experimental data [29]; and the migration mechanism of coalbed methane was studied by analyzing the evolution stage of coalbed methane [30]. However, in terms of in situ stress and permeability, most scholars take the 


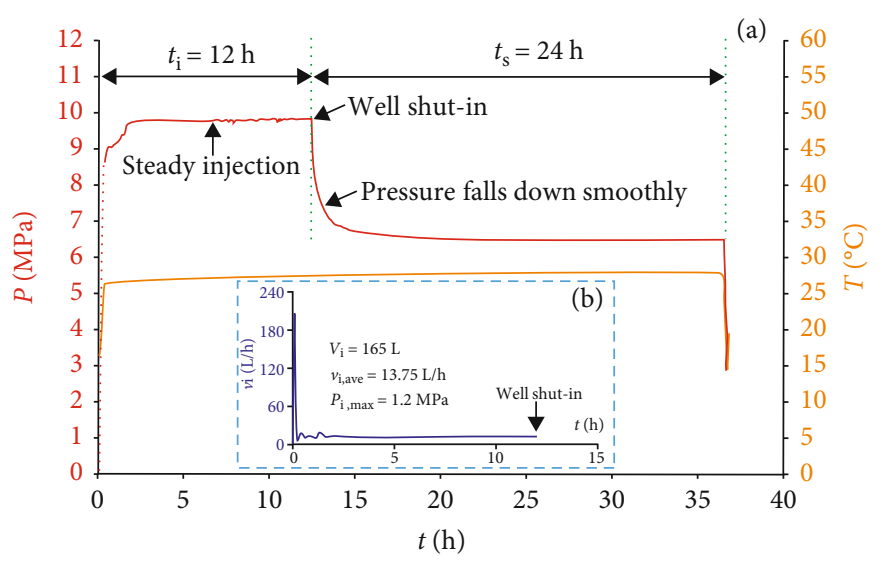

FIGURE 2: Injection/falloff curves of an actual CBM well: (a) relationship between pressure/temperature and time; (b) the relationship between the injection rate at the surface and time: $V_{\mathrm{i}}$ represents the total injection volume, $v_{\mathrm{i} \text {,ave }}$ represents the average injection rate at the surface, $P$ represents the pressure, $P_{\mathrm{i}}$ represents the maximum injection pressure at the surface, $t$ represents the time, $t_{\mathrm{i}}$ represents the injection time, $t_{\mathrm{s}}$ represents the well shut-in time, and $T$ represents the coal reservoir temperature.

eastern part of the Ordos basin as the study area, and few scholars have systematically studied the Liulin area [31-35]. Therefore, the distribution characteristics of in situ stress and its influence on permeability in the Liulin area still need more systematic study.

In this study, the correlations among parameters such as in situ stress, permeability, and burial depth were determined by statistical analysis and regression analysis using data from 35 coalbed methane wells in the Liulin area. Finally, the influence of in situ stress on the permeability of the coal reservoir in the Liulin area is revealed, which provides a basis for the reasonable exploration and development of coalbed methane in this area.

\section{Geological Setting}

Liulin area is located in the west of Shanxi Province (Figure 1(a)). The geographical coordinates are $110^{\circ} 44^{\prime} 00^{\prime \prime}$ $\sim 110^{\circ} 53^{\prime} 00^{\prime \prime}$ east longitude and $37^{\circ} 21^{\prime} 00^{\prime \prime} \sim 37^{\circ} 31^{\prime} 00^{\prime \prime}$ north latitude. The east-west width of this area is approximately $10.5 \mathrm{~km}$ and the north-south length is approximately $18.5 \mathrm{~km}$, covering an area of $194.4156 \mathrm{~km}^{2}$ (Figure 1(b)).

The structural position of the Liulin area is located in the north-south tectonic belt from the east bank of the Yellow River to the west slope of Lüliang Mountain. It is a monoclinic structure inclined to the west, and some secondary folds are developed on the monoclinic structure. There are few faults in this area and its structure is stable. Only in the north of the area are two large normal faults in the south and north of Jucaita and some small faults derived from them (Figure 1(c)). The topography of this area is high in the east and south and low in the west and north. The surface erosion is serious, and the surface water system develops with the topography. There are 14 coal seams in this area (Figure 1(d)), and the main coal-bearing strata are the Shanxi Formation and Taiyuan Formation, including 9 in the Taiyuan Formation and 5 in the Shanxi Formation $[24,36]$. The main coal seams for coalbed methane extraction are

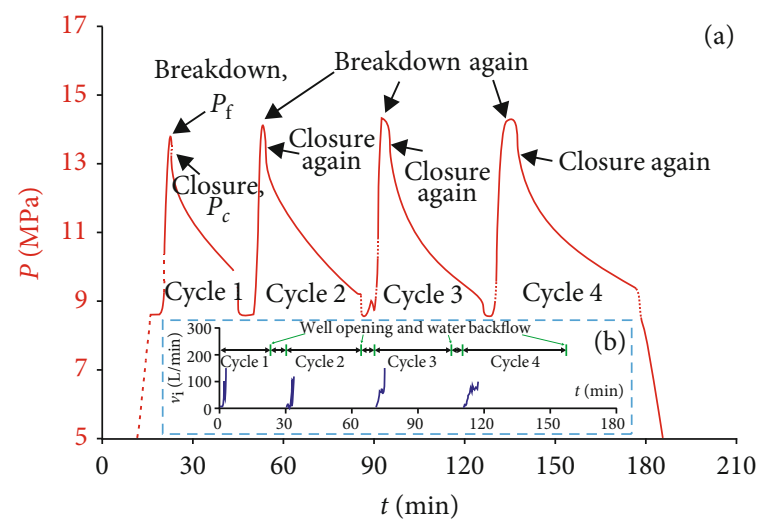

FIGURE 3: In situ stress measurement curve of an actual CBM well: (a) relationship between pressure and time; (b) relationship between the injection rate and time at the surface: $P_{\mathrm{f}}$ represents the fracturing pressure and $P_{\mathrm{c}}$ represents the closing pressure.

the No. $3+4$ and No. 5 coal seams in the Shanxi Formation and No. $8+9$ coal seam in the Taiyuan Formation [26]. The Taiyuan Formation was affected by an epicontinental sea and the coal seams were formed in a tidal flat environment after marine regression [37]. However, when the Shanxi Formation was deposited, the environment evolved to a prograded delta, and coal seams were formed on the floodplain of the delta interdistributary area [6].

\section{Methodology}

3.1. Test Method. The calculation of in situ stress often requires some parameters. To obtain these parameters, the coalbed methane well test method is generally adopted [31, 33]. The basic principle of this test is that by changing the pressure of the well, the equilibrium state of the fluid flow in the reservoir will be broken. And a pressure disturbance will be caused at the bottom of the well, which will continue 
TABLE 1: Injection/falloff and in situ stress test parameters in the Liulin area.

\begin{tabular}{|c|c|c|c|c|c|c|c|c|c|c|}
\hline Sample & $H(\mathrm{~m})$ & $K(\mathrm{mD})$ & $T\left({ }^{\circ} \mathrm{C}\right)$ & $P_{\mathrm{o}}(\mathrm{MPa})$ & $P_{c}(\mathrm{MPa})$ & $P_{\mathrm{f}}(\mathrm{MPa})$ & $\sigma_{\mathrm{h}}(\mathrm{MPa})$ & $\sigma_{\mathrm{H}}(\mathrm{MP})$ & $\sigma_{\mathrm{v}}(\mathrm{MPa})$ & $\lambda$ \\
\hline Well 1 & 479.32 & 0.83 & 23.61 & 4.39 & 8.82 & 9.42 & 8.82 & 13.45 & 12.94 & 0.86 \\
\hline Well 2 & 486.91 & 1.43 & 25.35 & 2.94 & 6.98 & 8.17 & 6.98 & 10.63 & 13.15 & 0.67 \\
\hline Well 3 & 488.00 & 0.03 & 24.57 & 3.62 & 11.04 & 12.12 & 11.04 & 18.17 & 13.18 & 1.11 \\
\hline Well 4 & 495.25 & 0.06 & 24.72 & 4.21 & 9.31 & 10.42 & 9.31 & 14.10 & 13.37 & 0.88 \\
\hline Well 5 & 539.50 & 1.92 & 26.55 & 4.82 & 6.50 & 7.75 & 6.50 & 7.73 & 14.57 & 0.49 \\
\hline Well 6 & 540.05 & 0.09 & 28.35 & 2.23 & 12.66 & 14.16 & 12.66 & 22.39 & 14.58 & 1.20 \\
\hline Well 7 & 553.66 & 0.16 & 28.60 & 5.07 & 13.24 & 13.67 & 13.24 & 21.78 & 14.95 & 1.17 \\
\hline Well 8 & 562.59 & 0.06 & 28.40 & 5.10 & 13.31 & 13.60 & 13.31 & 22.03 & 15.19 & 1.16 \\
\hline Well 9 & 564.80 & 0.64 & $\mathrm{~N}$ & 2.58 & 8.19 & 9.19 & 8.19 & 13.60 & 15.25 & 0.71 \\
\hline Well 10 & 577.45 & 0.28 & 28.00 & 2.95 & 12.15 & 13.36 & 12.15 & 20.94 & 15.59 & 1.06 \\
\hline Well 11 & 584.35 & 0.08 & 26.80 & 4.94 & 15.00 & 15.11 & 15.00 & 25.75 & 15.78 & 1.29 \\
\hline Well 12 & 585.75 & 0.04 & 28.20 & 3.03 & 10.40 & 11.48 & 10.40 & 17.49 & 15.82 & 0.88 \\
\hline Well 13 & 611.26 & 0.12 & 29.30 & 5.43 & 16.01 & 17.56 & 16.01 & 25.84 & 16.50 & 1.27 \\
\hline Well 14 & 617.30 & 0.10 & 31.10 & 5.42 & 14.82 & 15.22 & 14.82 & 24.62 & 16.67 & 1.18 \\
\hline Well 15 & 620.74 & $\mathrm{~N}$ & $\mathrm{~N}$ & $\mathrm{~N}$ & 17.73 & 18.99 & 17.73 & 29.54 & 16.76 & 1.41 \\
\hline Well 16 & 624.23 & $\mathrm{~N}$ & $\mathrm{~N}$ & $\mathrm{~N}$ & 12.61 & 12.87 & 12.61 & 21.23 & 16.85 & 1.00 \\
\hline Well 17 & 671.55 & 0.26 & 28.75 & 5.41 & 13.00 & 13.60 & 13.00 & 20.79 & 18.13 & 0.93 \\
\hline Well 18 & 678.55 & 0.13 & 29.00 & 5.59 & 13.42 & 13.96 & 13.42 & 21.51 & 18.32 & 0.95 \\
\hline Well 19 & 698.76 & 0.06 & 30.10 & 6.29 & 14.38 & 15.22 & 14.38 & 22.43 & 18.87 & 0.98 \\
\hline Well 20 & 710.10 & 0.11 & 30.06 & 7.49 & 15.71 & 17.04 & 15.71 & 23.40 & 19.17 & 1.02 \\
\hline Well 21 & 719.54 & 0.06 & 30.71 & 6.82 & 16.47 & 17.16 & 16.47 & 26.23 & 19.43 & 1.10 \\
\hline Well 22 & 746.19 & 0.11 & 30.20 & 8.33 & 16.10 & 16.88 & 16.10 & 23.89 & 20.15 & 0.99 \\
\hline Well 23 & 759.33 & 0.26 & 28.70 & 6.58 & 13.43 & 11.33 & 13.43 & 23.18 & 20.50 & 0.89 \\
\hline Well 24 & 760.97 & 0.02 & 28.20 & 6.55 & 13.63 & 14.47 & 13.63 & 20.67 & 20.55 & 0.83 \\
\hline Well 25 & 760.97 & 0.18 & 30.50 & 8.41 & 15.67 & 16.81 & 15.67 & 22.59 & 20.55 & 0.93 \\
\hline Well 26 & 769.48 & 0.62 & 33.15 & 8.25 & 14.48 & 16.03 & 14.48 & 19.96 & 20.78 & 0.83 \\
\hline Well 27 & 817.16 & $\mathrm{~N}$ & $\mathrm{~N}$ & $\mathrm{~N}$ & 14.73 & 18.42 & 14.73 & 18.09 & 22.06 & 0.74 \\
\hline Well 28 & 862.83 & $\mathrm{~N}$ & $\mathrm{~N}$ & $\mathrm{~N}$ & 12.11 & 12.55 & 12.11 & 18.22 & 23.30 & 0.65 \\
\hline Well 29 & 871.96 & 1.70 & 27.76 & 6.43 & 13.65 & 14.22 & 13.65 & 21.10 & 23.54 & 0.74 \\
\hline Well 30 & 913.68 & $\mathrm{~N}$ & $\mathrm{~N}$ & $\mathrm{~N}$ & 11.39 & 12.76 & 11.39 & 15.43 & 24.67 & 0.54 \\
\hline Well 31 & 965.15 & 0.07 & 35.90 & 8.90 & 17.72 & 18.05 & 17.72 & 27.01 & 26.06 & 0.86 \\
\hline Well 32 & 973.90 & 0.21 & 36.80 & 9.05 & 16.85 & 17.59 & 16.85 & 24.71 & 26.30 & 0.79 \\
\hline Well 33 & 1013.59 & 1.39 & 32.67 & 7.85 & 14.87 & 15.47 & 14.87 & 22.09 & 27.37 & 0.68 \\
\hline Well 34 & 1016.00 & 0.18 & 38.50 & 9.34 & 16.89 & 18.29 & 16.89 & 23.84 & 27.43 & 0.74 \\
\hline Well 35 & 1019.85 & 2.26 & 32.52 & 7.08 & 16.42 & 20.91 & 16.42 & 22.07 & 27.54 & 0.70 \\
\hline
\end{tabular}

to expand around the well over time until a new equilibrium state is formed. Therefore, we use the test instrument to record the change of bottom hole pressure with time; the parameters we need can be obtained. This test mainly includes two parts: the injection/falloff test and the multicycle hydraulic fracturing method.

The process of the injection/falloff test is first to inject water into the well with a constant rate and low injection pressure (lower than the fracture pressure of coal). After a period of time, a high pressure (higher than the original reservoir pressure) distribution area will be generated around the well, and then, the well is closed, allowing the pressure to gradually balance with the original reservoir pressure.
During both the injection and shut-in periods, the change of bottom hole pressure with time is recorded (Figure 2). Finally, the data are analyzed by using the semilog (Horner) and double-log linear analysis methods; the reservoir pressure $\left(P_{\mathrm{o}}\right)$, permeability $(K)$, and other parameters of the coal seam can be obtained $[6,38]$.

In situ stress is usually measured by the multicycle hydraulic fracturing method $[33,39,40]$. The process of hydraulic fracturing is briefly described as follows: in the initial stage of water injection, the fractures of target seams are closed due to the small pressure in the fractures (less than the fracture closure pressure), while the fractures are opened when the pressure in them increases to greater than the 


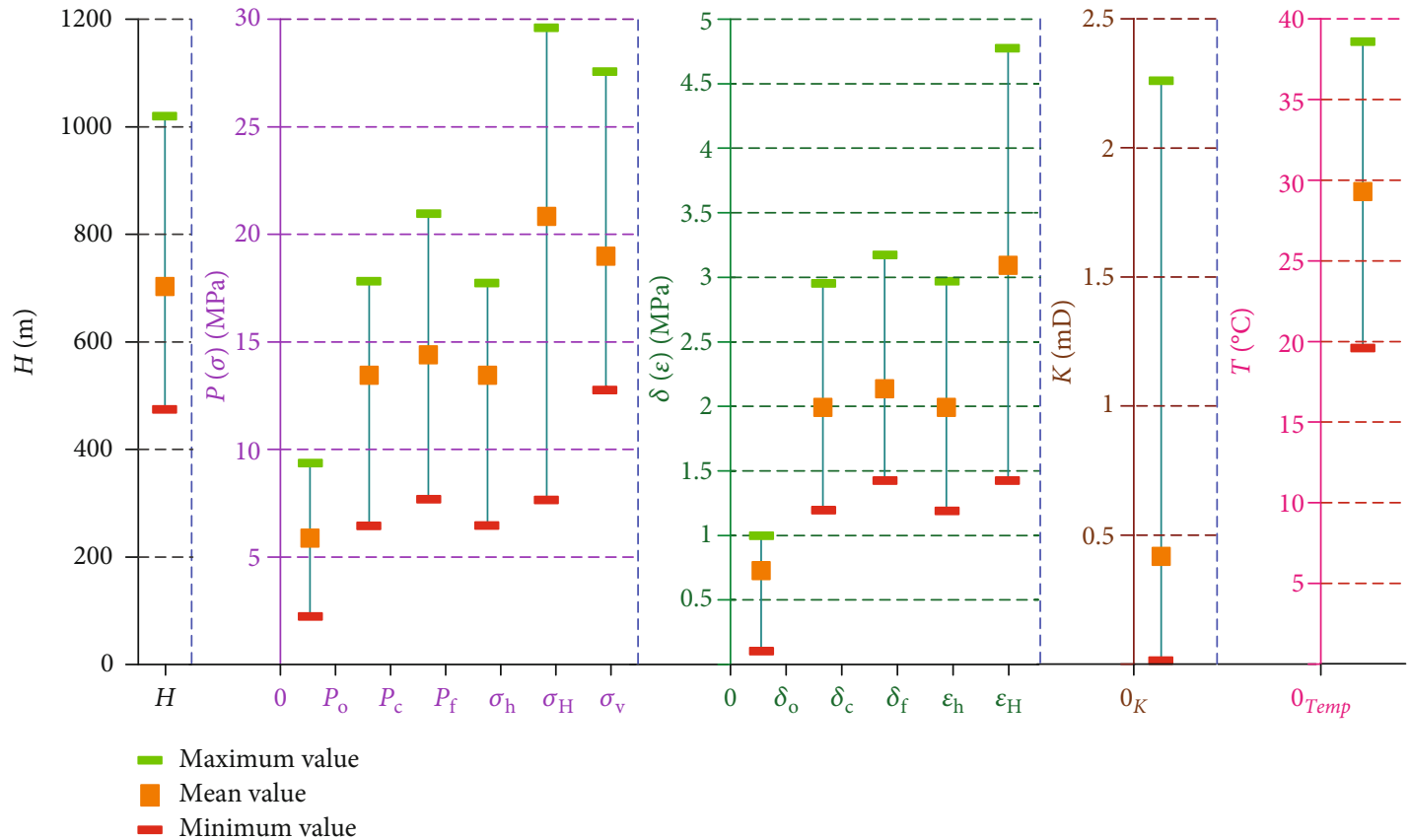

FIGURE 4: Stock chart of injection/falloff well test and in situ stress measurement parameters in Liulin area. $H$ : represents the burial depth; $P_{\mathrm{o}}$ : represents the initial reservoir pressure; $P_{\mathrm{c}}$ : represents closure pressure; $P_{f}$ : represents fracture pressure; $\sigma_{\mathrm{h}}$ : represents the minimum horizontal principal stress; $\sigma_{\mathrm{H}}$ : represents the maximum horizontal principal stress; $\sigma_{\mathrm{v}}$ : represents vertical stress; $\delta_{\mathrm{o}}$ : represents the initial reservoir pressure gradient; $\delta_{c}$ : represents closure pressure gradient; $\delta_{\mathrm{f}}$ : represents fracture pressure gradient; $\varepsilon_{\mathrm{h}}$ : represents the minimum horizontal principal stress gradient; $\varepsilon_{\mathrm{H}}$ : represents the maximum horizontal principal stress gradient; $K$ : represents the permeability; Temp: represents the reservoir temperature.

closing pressure. At this point, the water injection will be stopped, and the pressure in the fracture will gradually decrease over time. By using the time square root method to analyze the curve of the pressure changing with time, the fracture pressure $\left(P_{f}\right)$ and closure pressure $\left(P_{c}\right)$ can be further obtained. To reduce the error, the above process is generally carried out in four cycles, and two or three cycles with clear fracturing and closing effects were chosen for analysis (Figure 3).

3.2. Calculation Method. The horizontal principal stress can be calculated by using the parameters obtained from the above tests, including reservoir pressure, closure pressure, and fracture pressure. It is generally considered that the minimum horizontal principal stress is equivalent to the closure pressure [41].

$$
\sigma_{\mathrm{h}}=P_{\mathrm{c}}
$$

where $\sigma_{\mathrm{h}}$ is the minimum horizontal principal stress $(\mathrm{MPa})$.

The maximum horizontal principal stress can be calculated as follows [42]:

$$
\sigma_{\mathrm{H}}=3 P_{c}-P_{o}-P_{f}+T
$$

where $\sigma_{\mathrm{H}}$ is the maximum horizontal principal stress $(\mathrm{MPa})$, $P_{\mathrm{c}}$ is the closure pressure $(\mathrm{MPa}), P_{f}$ is the fracture pressure
$(\mathrm{MPa}), P_{o}$ is the rock pore pressure (initial reservoir pressure), and $T$ is the tensile strength of the rock around the borehole (MPa), and the value of $T$ in this study is 0.8 .

The vertical stress is equivalent to the gravity of the overlying rock and is proportional to the depth. Brown and Hock collected 116 original in situ stress test data from all over the world and analyzed the relationship between vertical stress and depth as follows [1]:

$$
\sigma_{\mathrm{v}}=0.027 \mathrm{H},
$$

where $\sigma_{\mathrm{v}}$ is the vertical stress $(\mathrm{MPa})$ and $H$ is the burial depth (m).

\section{Results}

4.1. Results of In Situ Stress and Injection/Falloff Well Tests. A total of 35 injection/falloff and in situ stress test data were collected, and the data is plotted in Table 1. It can be seen that at coal seam burial depths $(H) 479.32-1019.85 \mathrm{~m}$ (average $704.59 \mathrm{~m})$, the initial reservoir pressure $\left(P_{\mathrm{o}}\right)$ is 2.23-9.34 $\mathrm{MPa}$ (average 5.84 $\mathrm{MPa}$ ) and the pressure gradient $\left(\delta_{\mathrm{o}}\right)$ is $0.10-0.98 \mathrm{MPa} / 100 \mathrm{~m}$ (average $0.73 \mathrm{MPa} / 100 \mathrm{~m}$ ), which represent an underpressured reservoir. The closure pressure $\left(P_{\mathrm{c}}\right)$ is $6.50-17.73 \mathrm{MPa}$ (average $13.42 \mathrm{MPa}$ ), and the pressure gradient $\left(\delta_{c}\right)$ is $1.21-2.98 \mathrm{MPa} / 100 \mathrm{~m}$ (average $1.98 \mathrm{MPa} / 100 \mathrm{~m})$. The coal seam fracture pressure $\left(P_{\mathrm{f}}\right)$ is 7.75-20.91 $\mathrm{MPa}$ (average 14.40 $\mathrm{MPa}$ ), and the pressure 


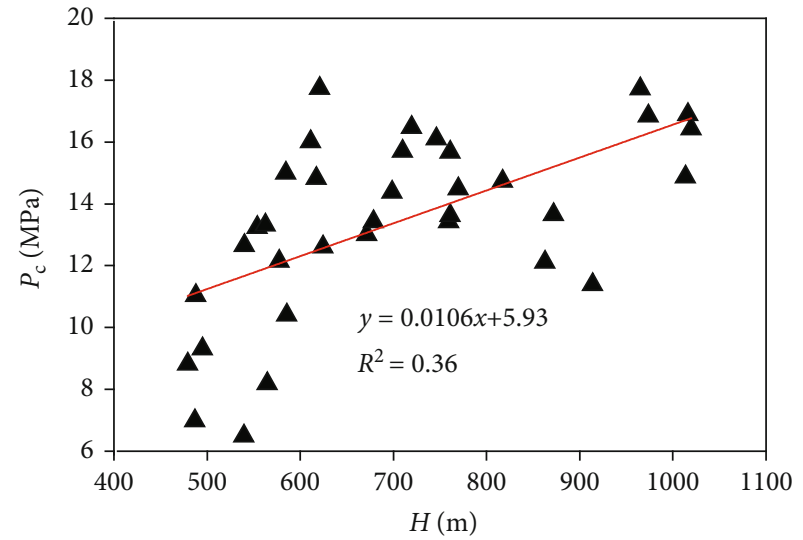

(a)

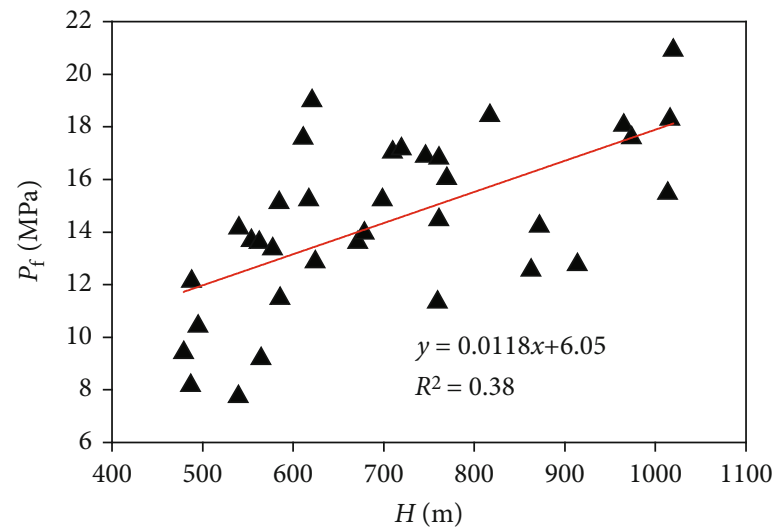

(c)

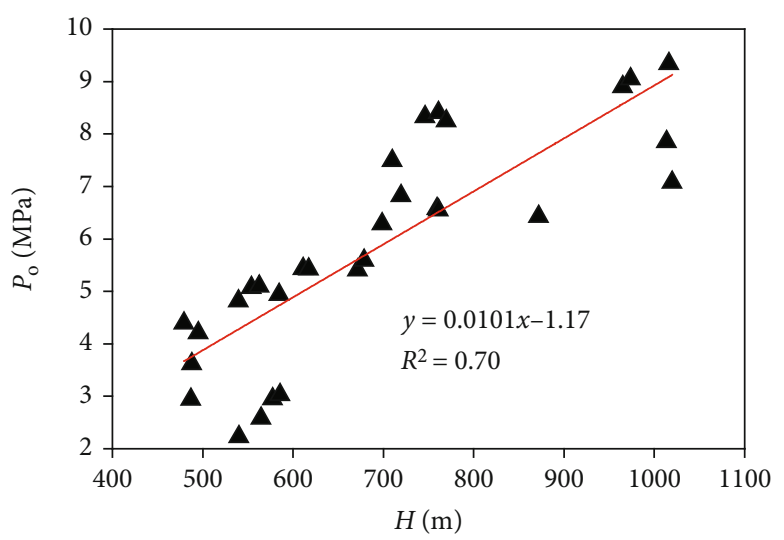

(b)

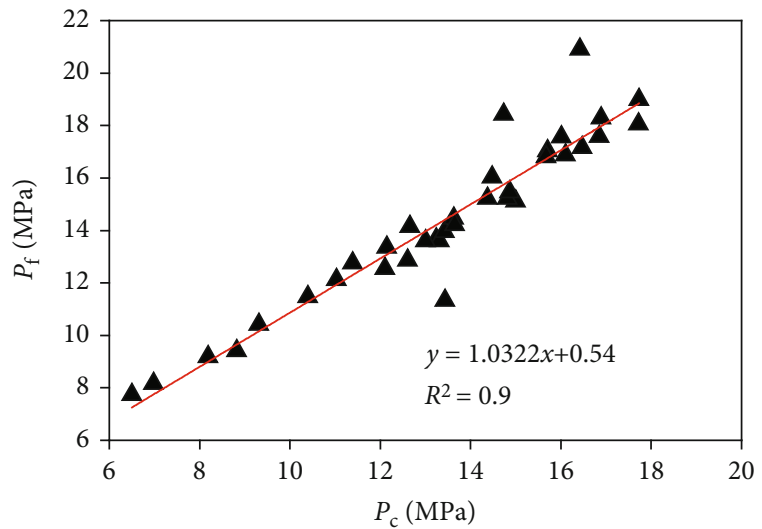

(d)

FIgURE 5: Scatter diagrams of reservoir pressure, fracture pressure, closure pressure, and burial depth.

gradient $\left(\delta_{\mathrm{f}}\right)$ is $1.40-3.38 \mathrm{MPa} / 100 \mathrm{~m}$ (average $2.12 \mathrm{MPa} / 100 \mathrm{~m}$ ). The coal reservoir temperature $(T)$ is $23.61-38.50^{\circ} \mathrm{C}$ with an average of $29.55^{\circ} \mathrm{C}$ (Figure 4). The permeability $(K)$ of coal reservoirs is $0.02-2.26 \mathrm{mD}$ (average $0.45 \mathrm{mD}$ ), most of which are less than $1 \mathrm{mD}$. This indicates that the study area is dominated by coal reservoirs with low permeability.

According to the above test results, the horizontal principal stress and vertical stress can be calculated by formulas (1), (2), and (3), respectively. The minimum horizontal principal stress $\left(\sigma_{\mathrm{h}}\right)$ is $6.50-17.73 \mathrm{MPa}$ with an average of $13.42 \mathrm{MPa}$, for which the stress gradient $\left(\varepsilon_{\mathrm{h}}\right)$ is $1.21-2.95 \mathrm{MPa} / 100 \mathrm{~m}$ with a mean value of $2.0 \mathrm{MPa} / 100 \mathrm{~m}$. The maximum horizontal principal stress $\left(\sigma_{\mathrm{H}}\right)$ is $7.73-29.54 \mathrm{MPa}$ with an average of $20.76 \mathrm{MPa}$, and the stress gradient $\left(\varepsilon_{\mathrm{H}}\right)$ is 1.43 $4.76 \mathrm{MPa} / 100 \mathrm{~m}$ and averaged at $3.1 \mathrm{MPa} / 100 \mathrm{~m}$. And the vertical stress $\left(\sigma_{\mathrm{v}}\right)$ is $12.94-27.54 \mathrm{MPa}$ with an average of $19.02 \mathrm{MPa}$ (Figure 4). In general, the maximum horizontal principal stress in the study area is dominant compared to other stresses.

The results of in situ stress and injection/falloff well tests were analyzed, and it was found that there was a significant linear relationship between the initial reservoir pressure and burial depth (Figure 5(b)). The closure pressure and fracture pressure have a linear relation with burial depth, but the squares of the two correlation coefficients are small ( 0.36 and 0.38 , respectively) (Figures 5(a) and 5(c)). Besides, there is a very obvious linear relationship between closure pressure and fracture pressure (Figure 5(d)).

4.2. Principal Stress Variation with Depth. According to the relationship between horizontal principal stress and vertical stress, the stress field is usually divided into a static stress field, dynamic field, and quasistatic stress field [6]. It is found that in different depth zones, the variation trend of the three in situ stresses is different, and the stress field also shows different results accordingly (Figure 6).

At depths $<800 \mathrm{~m}$, the three in situ stresses all increase with the increase of burial depth, and compared with the vertical stress, the maximum and minimum horizontal principal stresses increase faster. The relationship of these three in situ stresses in the coal reservoir is $\sigma_{\mathrm{H}} \geq \sigma_{\mathrm{v}}>\sigma_{\mathrm{h}}$, that is, the type of stress field is a dynamic field, and the coal reservoir is under a state of extrusion from horizontal direction at this time.

At depths $>800 \mathrm{~m}$, as the burial depth increases, the maximum and minimum horizontal principal stress growth rates decrease and gradually tend to be stable, while the vertical stress still increases at the previous growth rate and 


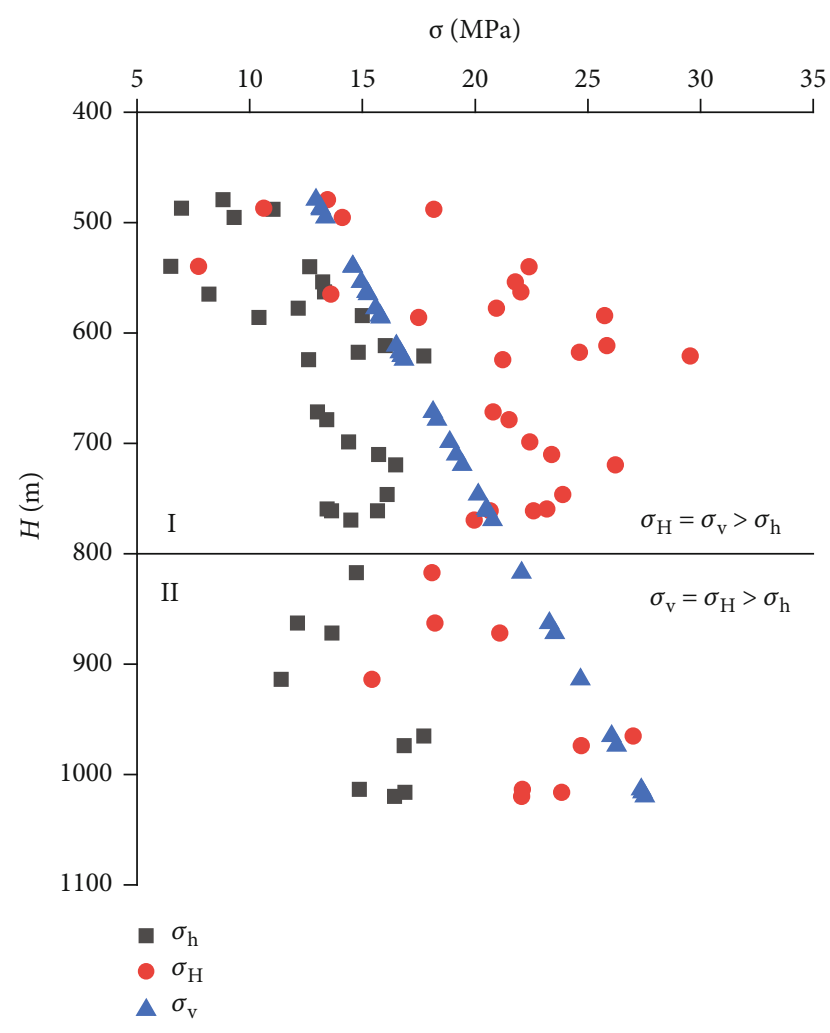

FIGURE 6: Scatter diagrams of maximum horizontal principle stress, minimum horizontal principle stress, vertical stress, and burial depth (I represents dynamic field; II represents static stress field).

becomes the dominant stress. The relationship of these three in situ stresses in the coal reservoir is $\sigma_{\mathrm{v}} \geq \sigma_{\mathrm{H}}>\sigma_{\mathrm{h}}$, the type of stress field has been transformed into a static stress field, and the coal reservoir is no longer in a horizontal extrusion state in this depth zone.

4.3. The Lateral Stress Coefficient with Depth. To quantitatively reveal the stress state at the specific burial depth, the parameter of the lateral stress coefficient is introduced. Generally, the lateral stress coefficient is defined as the ratio of the average horizontal principal stress to the vertical stress and is expressed as

$$
\lambda=\frac{\sigma_{H}+\sigma_{h}}{2 \sigma_{v}}
$$

where $\lambda$ is the lateral stress coefficient.

Through calculation, it can be seen that the lateral stress coefficient of the Liulin area ranges from 0.49 to 1.41, with an average of 0.93 . These values are between the HoekBrown inner and outer in situ stress envelopes representing the relationship between the ratio and the burial depth worldwide and are close to the Chinese in situ stress envelope (Figure 7). On the whole, the lateral stress coefficient in the study area decreases with the increase of burial depth. However, the coefficient shows different characteristics in different depth zones. At depths $<800 \mathrm{~m}$, this parameter is 0.49 -
1.41 , with an average of 1.03 . Moreover, most values are greater than 0.9 , which further indicates that the horizontal principal stress is dominant in this depth zone. At depths $>800 \mathrm{~m}$, this parameter is relatively stable, with a range of $0.54-0.86$ and an average of 0.72 . The value of this parameter is less than 0.9 , which further indicates that the vertical stress is dominant in this depth zone. In general, the variation trend of the lateral stress coefficient in different depth zones also well reveals the change of stress field from a dynamic field to a static stress field with the increase of burial depth.

4.4. Permeability Variation with Depth. Reservoir permeability is one of the key factors that determine coalbed methane productivity $[33,43]$. The permeability includes matrix permeability and fracture system permeability; the former is almost negligible, and the latter is the main factor to control the percolation conditions of the coal reservoir [44]. Permeability is mainly affected by geological factors such as stress field, burial depth, coal structure, and fractures $[5,45]$.

With the increase of burial depth, the permeability shows different characteristics in the two depth zones (Figure 8). At depths $<800 \mathrm{~m}$, the permeability decreases with the increase of burial depth, which is $0.02-1.92 \mathrm{mD}$, with an average of $0.32 \mathrm{mD}$. At depths $>800 \mathrm{~m}$, the average permeability of the coal reservoir is $0.97 \mathrm{mD}$, most of which are still very small, while a few increase relative to the shallow part. Compared with the variation of in situ stress with depth, the permeability inflection points at various depths are consistent with the transition points of the stress field types and states at the corresponding depths.

\section{Discussions}

5.1. Permeability Variation Characteristics under the Influence of Stress Field. It is well known that permeability is affected by in situ stress, so there must be a parameter related to in situ stress, which has a good correlation with permeability. To find this parameter, the minimum horizontal principal stress, maximum horizontal principal stress, vertical stress, and lateral stress coefficients were fitted to the permeability (Figure 9).

It can be seen from the results that the relationship between permeability and vertical stress is not obvious (Figure 9(c)). And the permeability has a weak negative exponential relationship with the maximum and minimum horizontal principal stress, respectively (both squared correlation coefficients are less than 0.3) (Figures 9(a) and $9(\mathrm{~b}))$. It is worth mentioning that there is a good negative exponential relationship between permeability and lateral stress coefficient, and the squared correlation coefficients between them can reach 0.6 (Figure 9(d)). This is because the lateral stress coefficient combines the three in situ stresses, and the size of this parameter represents the type of stress field. The smaller the lateral stress coefficient is, the more the stress field tends to the static stress field, and the pores and fractures in coal reservoirs are more likely to expand, resulting in higher permeability. The 


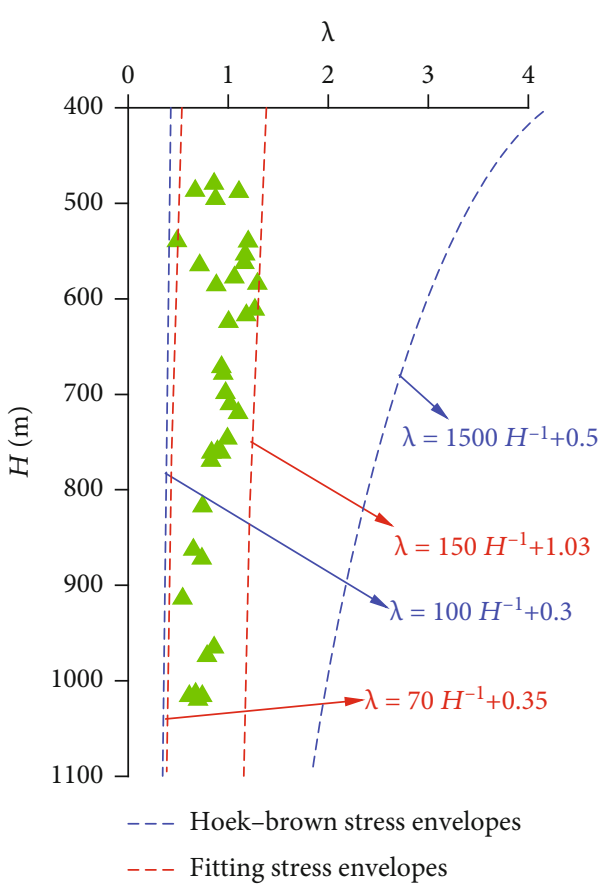

(a)

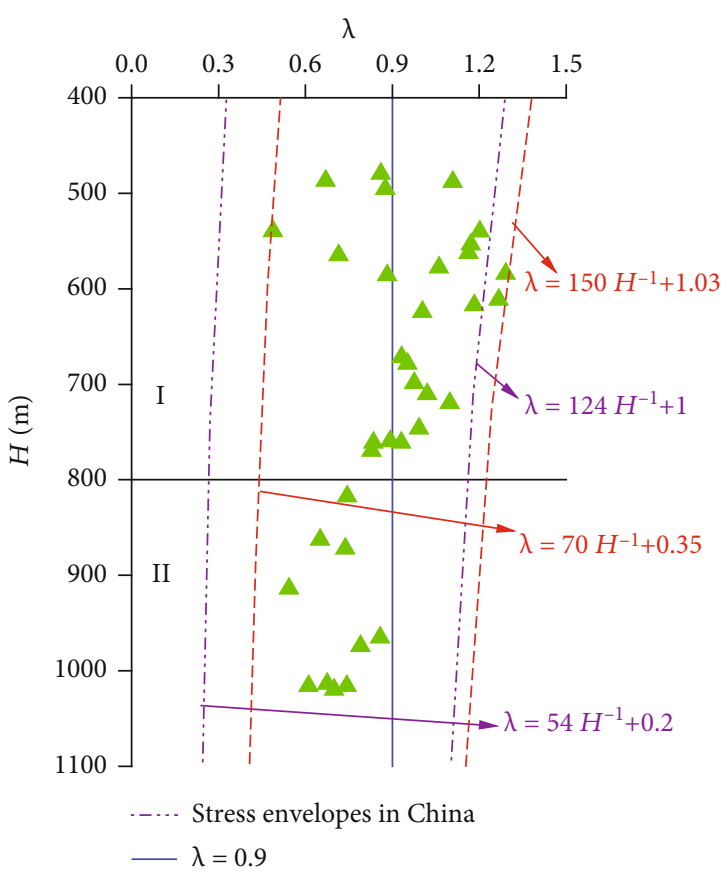

(b)

FIGURE 7: Scatter diagrams of coefficient of lateral stress and burial depth: (a) relationship between the lateral stress coefficient and the HoekBrown stress envelope; (b) the relationship between the lateral stress coefficient and the stress envelope in China.

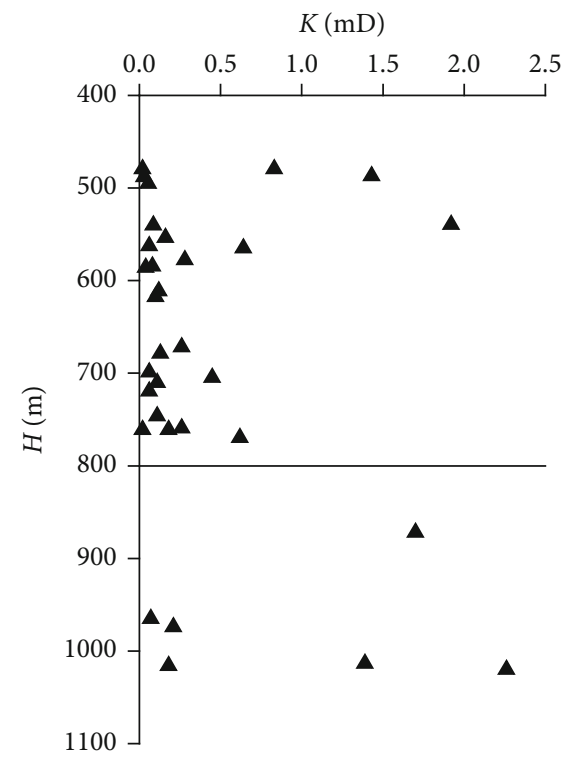

FIGURE 8: Scatter diagram of permeability and burial depth.

larger the lateral stress coefficient is, the more the stress field tends to the dynamic field, and the pore and fractures in the coal reservoir are seriously compressed, leading to a smaller permeability. The fitting formula of permeability and lateral stress coefficient is as follows:

$$
k=13.45 e^{-\lambda / 0.29}-0.24 .
$$

However, it should be noted that the data points which cause a poor correlation between permeability and in situ stress have two common characteristics, that is, large burial depth and high permeability (Figures 9(a)-9(c)). To explore the causes of these deep high permeability data points, the structural characteristics of high permeability $(K>0.5 \mathrm{mD})$ coal reservoirs are analyzed (Table 2). As can be seen from Table 2, the three higher permeability points located deep (well 29, well 33, and well 35) are all located in the axial part of the syncline structure. Therefore, this article believes that it is these special structures that lead to the improvement of the permeability of deep coal reservoirs. Usually, when the horizontal strata fold, the strata tend to shorten and cause bending deformation. If there is only a single and thick rock layer, the outer arc of the rock layer will be stretched along the layer direction, while the inner arc will be compressed toward the center direction. There is always a middle plane between the two sides, which is neither stretched nor compressed. As the outer arc is stretched, some fractures perpendicular to the tensile stress tend to expand (Figure 10(a)). If the rock layer is thin and there are multiple layers superimposed, each layer will slip along the layer during the folding process, which will often produce cracks between the rock layers (Figure 10(b)). Both of the above situations may lead to an increase of permeability.

5.2. Variation Model of Coal Reservoir Parameters in Different Burial Depth Zones. Based on the above results, a comprehensive analysis is carried out by establishing the variation model of coal reservoir parameters in different depth 


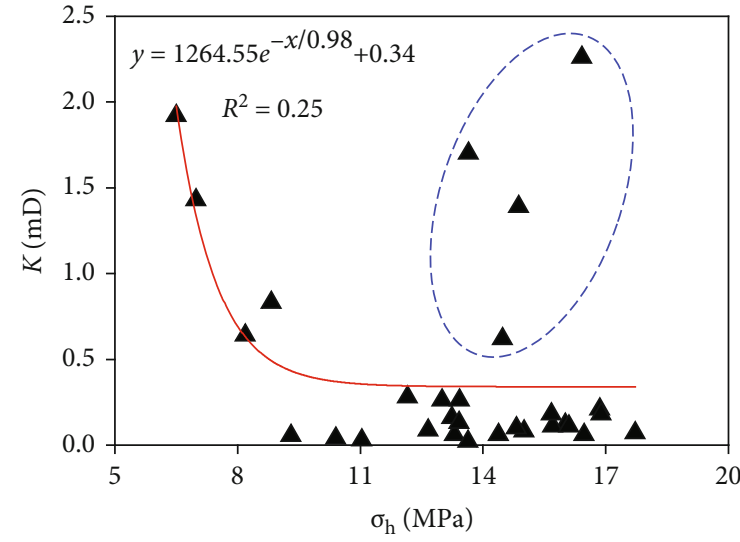

(a)

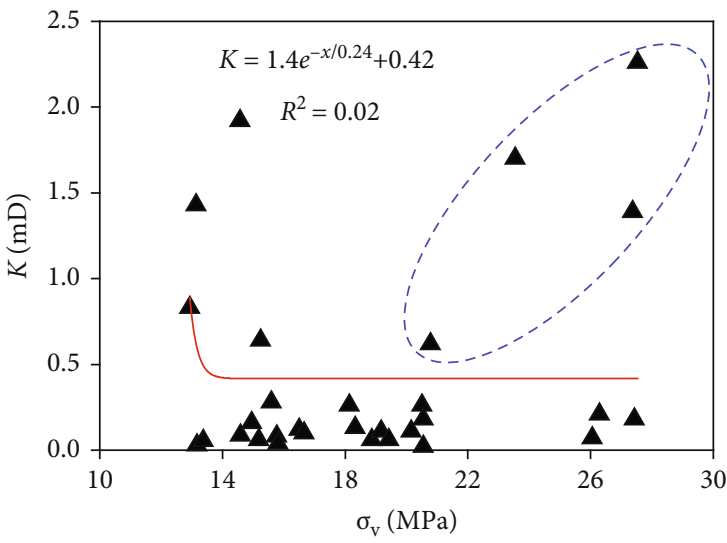

(c)

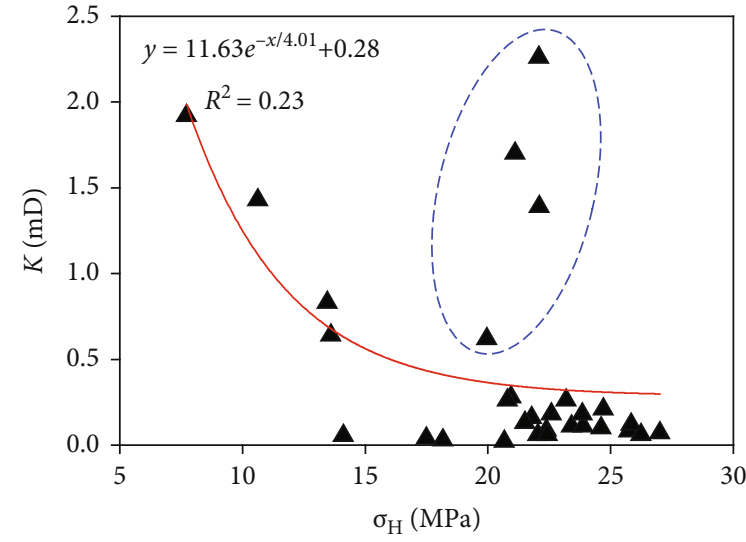

(b)

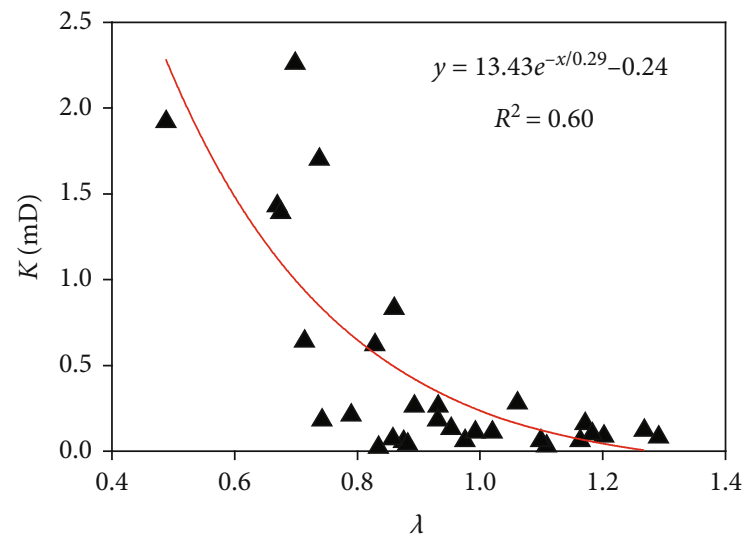

(d)

FIgURE 9: Scatter plot of permeability and some parameters.

TABLE 2: Statistical table of structural locations of data points with high permeability.

\begin{tabular}{lccc}
\hline Sample & $H(\mathrm{~m})$ & $K(\mathrm{mD})$ & Location \\
\hline Well 1 & 479.32 & 0.83 & No structure \\
Well 2 & 486.91 & 1.43 & No structure \\
Well 5 & 539.50 & 1.92 & No structure \\
Well 9 & 564.80 & 0.64 & The wing of a syncline \\
Well 26 & 769.48 & 0.62 & No structure \\
Well 29 & 871.96 & 1.70 & The axis of a syncline \\
Well 33 & 1013.59 & 1.39 & The axis of a syncline \\
Well 35 & 1019.85 & 2.26 & The axis of a syncline \\
\hline
\end{tabular}

zones (Figure 11). It can be seen from this figure that the curves of permeability and lateral stress coefficient with depth have a good correlation. At the same time, the permeability is affected by in situ stress and the coal seam structure, and the influencing mechanism is different in different depth zones.

At depths $<800 \mathrm{~m}$, the stress field of the coal reservoirs at most locations shows a dynamic field. The permeability is higher at the shallower locations, because the shallow coal seam bears less stress from three directions, which leads to the expansion of coal pores. On the other hand, the horizontal principal stresses of these high permeability coals are all less than the vertical stresses, indicating that they are in a state of horizontal stretch, which causes the cracks in the coal to expand more easily. The effects of these two aspects will increase the permeability of the coal seam. Subsequently, with the increase of burial depth, the in situ stress of coal reservoirs increases rapidly, and the maximum horizontal principal stress becomes dominant, which causes the coal reservoir to be severely compressed and its permeability to decrease rapidly.

At depths $>800 \mathrm{~m}$, the stress field of the coal reservoirs shows a static stress field. Because the in situ stresses in the three directions are all relatively high, the porosity and fracture of the coal seam are compressed seriously, so that the coal reservoir permeability in this depth zone is generally low. However, it should be noted that at some special structural locations, such as the axis of the syncline structure, it is still possible to increase the permeability due to the influence of tectonic activity (Figure 11). 


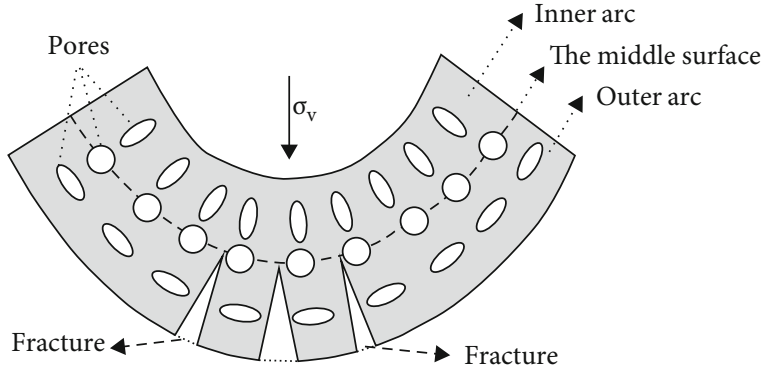

(a)

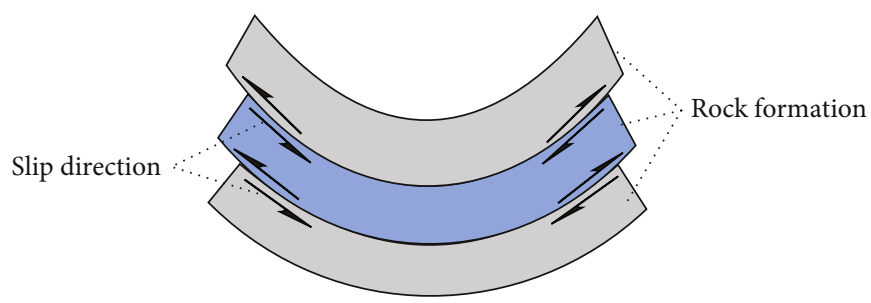

(b)

FIGURE 10: Diagram of the formation process of syncline structure: (a) variation characteristics of a layer of rock when it bends; (b) variation characteristics of multiple layers when they bend.

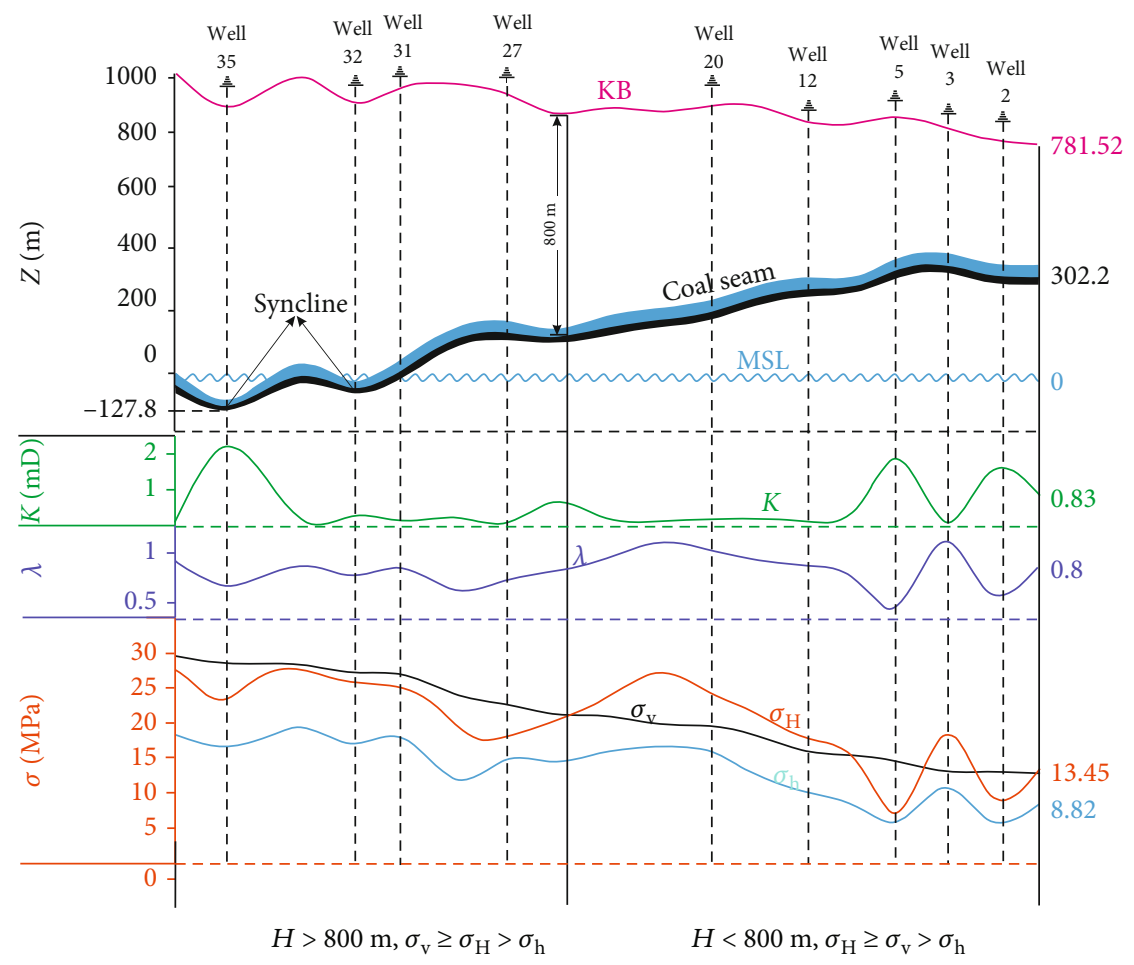

FIGURE 11: Variation trend of each parameter in different depth zones. Z: represents altitude, m; KB: represents the kelly bushing; MSL: represents mean sea level.

\section{Conclusions}

(1) With the increase of burial depth, the closure pressure, fracture pressure, and initial reservoir pressure all increase gradually; there is a very obvious linear relationship between the closure pressure and the fracture pressure. In general, there are two in situ stress states in the Liulin area. At depths $<800 \mathrm{~m}$, the relationship of the three in situ stresses in the coal reservoir is $\sigma_{\mathrm{H}} \geq \sigma_{\mathrm{v}}>\sigma_{\mathrm{h}}$. Compared with vertical stress, the horizontal principal stresses increase faster; at depths $>800 \mathrm{~m}$, the relationship of the three in situ stresses is transformed into $\sigma_{\mathrm{v}} \geq \sigma_{\mathrm{H}}>\sigma_{\mathrm{h}}$. And with the increase of burial depth, the horizontal principal stresses increase slowly and even become stable gradually
(2) The variation of coal permeability is mainly controlled by the influence of in situ stress on the pore-fracture system. At depths $<800 \mathrm{~m}$, because the in situ stress increases with the increase of burial depth, the permeability is a simple decreasing process with the increase of the depth. At depths $>800 \mathrm{~m}$, the porosity and fracture of coal reservoirs are compressed seriously due to the large in situ stress, resulting in the coal reservoir permeability in this depth zone being generally low. However, it is still possible to increase the permeability at some special structural locations due to the influence of tectonic activity

(3) Under the influence of data points with a large burial depth and high permeability, the fitting relationship between permeability and the three in situ stresses 
is poor. There is a good negative exponential relationship between permeability and the lateral stress coefficient (the fitting formula is as follows: $\left.k=13.45 e^{-\lambda / 0.29}-0.24\right)$; this is because the lateral stress coefficient combines the three in situ stresses, and the size of this parameter represents the type of the stress field. This indicates that the lateral stress coefficient can be used to predict the permeability better

\section{Data Availability}

All data, models, and code generated or used during the study appear in the submitted article.

\section{Conflicts of Interest}

The authors declare that they have no conflicts of interest.

\section{Acknowledgments}

This work was supported by the National Natural Science Foundation of China (Grant nos. 41802180 and 42072198), and the Fundamental Research Funds for the Central Universities (Grant no. 2652019211).

\section{References}

[1] E. Hoek and T. Brown, Underground Excavations in Rock, The Institute of Mining and Metallurgy, 1980.

[2] A. Iannacchione, T. S. Bajpayee, and L. Prosser, "Methods for determining roof fall risk in underground mines," Mining and Engineering, vol. 59, no. 11, pp. 47-53, 2007.

[3] H. Kang, X. Zhang, and L. Si, "Study on in-situ stress distribution law in deep underground coal mining areas," in ISRM International Symposium on Rock Mechanics, pp. 139-143, China, May 2009.

[4] M. Cai, L. Qiao, C. Li, H. Ji, and H. Peng, "New development of in-situ stress measurement in Chinese mines," in ISRM International Symposium on In-Situ Rock Stress, pp. 135-142, Beijing, China, August 2010.

[5] H. Fu, D. Yan, S. Yang, X. Wang, Z. Zhang, and M. Sun, "Characteristics of in situ stress and its influence on coalbed methane development: a case study in the eastern part of the southern Junggar basin, NW China," Energy Science \& Engineering, vol. 8, no. 2, pp. 515-529, 2020.

[6] Y. Li, D. Tang, H. Xu, and T. Yu, "In-situ stress distribution and its implication on coalbed methane development in Liulin area, eastern Ordos basin, China," Journal of Petroleum Science and Engineering, vol. 122, pp. 488-496, 2014.

[7] S. Chen, D.-Z. Tang, S. Tao, J. Zhao, Y. Li, and W.-Q. Liu, "Discussion about "critical depth" of deep coalbed methane in Zhengzhuang area, Qinshui basin," Meitan Xuebao/Journal China Coal Society, vol. 41, pp. 3069-3075, 2016.

[8] W. Ju, B. Jiang, Y. Qin et al., "The present-day in-situ stress field within coalbed methane reservoirs, Yuwang block, Laochang basin, south China," Marine and Petroleum Geology, vol. 102, pp. 61-73, 2019.

[9] R. Tyler, A. Scott, and W. Kaiser, Defining coalbed methane exploration fairways: an example from the Piceance basin, Rocky Mountain Foreland, Western United States, 1999.
[10] J. Q. Shi and S. Durucan, "A model for changes in coalbed permeability during primary and enhanced methane recovery," SPE Reservoir Evaluation and Engineering, vol. 8, no. 4, pp. 291-299, 2005.

[11] J. S. Bell, "In-situ stress and coal bed methane potential in Western Canada," Bulletin of Canadian Petroleum Geology, vol. 54, no. 3, pp. 197-220, 2006.

[12] R. Chatterjee and P. K. Pal, "Estimation of stress magnitude and physical properties for coal seam of Rangamati area, Raniganj coalfield, India," International Journal of Coal Geology, vol. 81, no. 1, pp. 25-36, 2010.

[13] H. Kang, X. Zhang, L. Si, Y. Wu, and F. Gao, "In-situ stress measurements and stress distribution characteristics in underground coal mines in China," Engineering Geology, vol. 116, no. 3-4, pp. 333-345, 2010.

[14] C. Ö. Karacan, J. P. Ulery, and G. V. R. Goodman, “A numerical evaluation on the effects of impermeable faults on degasification efficiency and methane emissions during underground coal mining," International Journal of Coal Geology, vol. 75, no. 4, pp. 195-203, 2008.

[15] Z. P. Meng, Y. D. Tian, and G. F. Li, "Characteristics of in-situ stress field in southern Qinshui basin and its research significance," Meitan Xuebao/Journal China Coal Society, vol. 35, no. 6, pp. 975-981, 2010.

[16] C. Liu, "Distribution laws of in-situ stress in deep underground coal mines," Procedia Engineering, vol. 26, pp. 909917, 2011.

[17] S. Li, D. Tang, Z. Pan, H. Xu, and W. Huang, "Characterization of the stress sensitivity of pores for different rank coals by nuclear magnetic resonance," Fuel, vol. 111, no. 3, pp. 746-754, 2013.

[18] M. H. Talebi, S. Heidari, M. Moosavi, and M. Rahimi, "In situ stress measurements of two hydropower projects in Iran by hydraulic fracturing method," Arabian Journal of Geosciences, vol. 8, no. 9, pp. 7073-7085, 2015.

[19] S. Tao, S. Chen, and Z. Pan, "Current status, challenges, and policy suggestions for coalbed methane industry development in China: a review," Energy Science \& Engineering, vol. 7, no. 4, pp. 1059-1074, 2019.

[20] C. Yang, J. Zhang, and X. Tang, "Microscopic pore types and its impact on the storage and permeability of continental shale gas, Ordos Basin,” Earth Science Frontiers, vol. 20, pp. 240 250, 2013.

[21] J. Zhao, D. Tang, W. Lin et al., "Permeability dynamic variation under the action of stress in the medium and high rank coal reservoir," Journal of Natural Gas Science and Engineering, vol. 26, pp. 1030-1041, 2015.

[22] D. Feng, H. Deng, Z. Zhou, X. Gao, and L. Cui, "Paleotopographic controls on facies development in various types of braid-delta depositional systems in lacustrine basins in China," Geoscience Frontiers, vol. 6, no. 4, pp. 579-591, 2015.

[23] S. Li, D. Tang, Z. Pan et al., "Geological conditions of deep coalbed methane in the eastern margin of the Ordos basin, China: implications for coalbed methane development," Journal of Natural Gas Science and Engineering, vol. 53, pp. 394402, 2018.

[24] X. Su, L. Zhang, and R. Zhang, "The abnormal pressure regime of the Pennsylvanian No. 8 coalbed methane reservoir in Liulin-Wupu district, eastern Ordos basin, China," International Journal of Coal Geology, vol. 53, no. 4, pp. 227-239, 2003.

[25] Y. Meng, D. Tang, and H. Xu, "CBM potential productivity assessment through fuzzy mathematics - a case study in Liulin 
mine area, Hedong Coalfield," Coal Geology of China, vol. 22, pp. 17-20, 2010.

[26] Y. Meng, D. Tang, H. Xu, C. Li, L. Li, and S. Meng, "Geological controls and coalbed methane production potential evaluation: a case study in Liulin area, eastern Ordos basin, China," Journal of Natural Gas Science and Engineering, vol. 21, pp. 95-111, 2014.

[27] S. Zhang, S. Tang, D. Tang, Z. Pan, and F. Yang, “The characteristics of coal reservoir pores and coal facies in Liulin district, Hedong coal field of China," International Journal of Coal Geology, vol. 81, no. 2, pp. 117-127, 2010.

[28] H. Xu, D. Tang, S. Tang et al., "Geologic and hydrological controls on coal reservoir water production in marine coalbearing strata: a case study of the carboniferous Taiyuan formation in the Liulin area, eastern Ordos basin, China," Marine and Petroleum Geology, vol. 59, pp. 517-526, 2015.

[29] Y. Li, D. Tang, H. Xu, D. Elsworth, and Y. Meng, "Geological and hydrological controls on water coproduced with coalbed methane in Liulin, eastern Ordos basin, China," AAPG Bulletin, vol. 99, no. 2, pp. 207-229, 2015.

[30] Y. Bao, C. Wei, and B. Neupane, "Generation and accumulation characteristics of mixed coalbed methane controlled by tectonic evolution in Liulin CBM field, eastern Ordos basin, China," Journal of Natural Gas Science and Engineering, vol. 28, no. 262-270, pp. 262-270, 2016.

[31] S. Chen, D. Tang, S. Tao et al., "In-situ stress measurements and stress distribution characteristics of coal reservoirs in major coalfields in China: implication for coalbed methane (CBM) development," International Journal of Coal Geology, vol. 182, pp. 66-84, 2017.

[32] S. P. Eng, J. Lan, C. L. Liu, Y. M. Ji, S. N. Li, and X. M. Zhang, "In-situ stress and coal reservoir pressure in southeast margin of Ordos basin and their coupling relations," Journal of China Coal Society, vol. 38, no. 1, pp. 122-128, 2013.

[33] J. Zhao, D. Tang, H. Xu et al., "Characteristic of in situ stress and its control on the coalbed methane reservoir permeability in the eastern margin of the Ordos basin, China," Rock Mechanics and Rock Engineering, vol. 49, no. 8, pp. 33073322, 2016.

[34] Y. Wan, H. Li, L. Yun, Z. Song, Y. Li, and P. Qi, "The field stress between late Jurassic and early Cretaceous in the eastern Ordos basin," Earth Science, vol. 42, no. 4, pp. 549-558, 2017.

[35] W. Ju, X. Niu, S. Feng et al., "Present-day in-situ stress field within the Yanchang formation tight oil reservoir of Ordos basin, central China," Journal of Petroleum Science and Engineering, vol. 187, article 106809, 2020.

[36] Z. Chen, N. Zhang, and S. Zhang, "The time and spatial evolution of sedimentary systems and coal accumulation centre in late Palaezoic coal-bearing measures on the eastern margin of Ordos basin," Earth Science-Journal of China University of Geosciences, vol. 14, pp. 357-366, 1989.

[37] L. I. Yong, J. Yang, Z. Pan, S. Meng, K. Wang, and X. Niu, "Unconventional natural gas accumulations in stacked deposits: a discussion of upper Paleozoic coal-bearing strata in the east margin of the Ordos basin, China," Acta Geologica Sinica-English Edition, vol. 93, no. 1, pp. 111-129, 2019.

[38] C. W. Hopkins, J. H. Frantz, R. W. Flumerfelt, and J. P. Spivey, "Pitfalls of injection/falloff testing in coalbed methane reservoirs," in SPE Permian Basin Oil and Gas Recovery Conference, Midland, TX, USA, March 1998.
[39] M. K. Hubbert and D. G. W. Willis, "Mechanics of hydraulic fracturing," Transactions of AIME, vol. 18, no. 1, pp. 369390, 1972.

[40] Q. Liu, Y. Cheng, L. Yuan, B. Tong, S. Kong, and R. Zhang, "CMM capture engineering challenges and characteristics of in-situ stress distribution in deep level of Huainan coalfield," Journal of Natural Gas Science and Engineering, vol. 20, pp. 328-336, 2014.

[41] B. C. Haimson and F. H. Cornet, "ISRM suggested methods for rock stress estimation-part 3: hydraulic fracturing (HF) and/or hydraulic testing of pre-existing fractures (HTPF)," International Journal of Rock Mechanics and Mining Sciences, vol. 40, no. 7-8, pp. 1011-1020, 2003.

[42] J. D. Bredehoeft, R. G. Wolff, W. S. Keys, and E. Shuter, "Hydraulic fracturing to determine the regional in situ stress field, Piceance basin, Colorado," Geological Society of America Bulletin, vol. 87, no. 2, p. 250, 1976.

[43] S. Wang, D. Elsworth, and J. Liu, "Mechanical behavior of methane infiltrated coal: the roles of gas desorption, stress level and loading rate," Rock Mechanics and Rock Engineering, vol. 46, no. 5, pp. 945-958, 2013.

[44] J. R. Enever and A. Hennig, The Relationship between Permeability and Effective Stress for Australian Coals and Its Implications with Respect to Coalbed Methane Exploration and Reservoir Modelling, University of Alabama, 1997.

[45] W. F. Brace, "A note on permeability changes in geologic material due to stress," Pure and Applied Geophysics, vol. 116, no. 4-5, pp. 627-633, 1978. 